\title{
Implementation of Total Quality Management in Some Saudi Public Sector Organizations
}

\author{
SALEM S. AL-QAHTANI \\ Associate Professor \\ and \\ MoAdDi M. Al-METHHEB \\ Assistant Professor \\ Department of Public Administration \\ College of Administrative Sciences \\ King Saud University, Riyadh, Saudi Arabia
}

( Received 1.1.1419H, and Accepted 16.6.1419H )

\begin{abstract}
This study focuses on the efforts of some Saudi public organizations to implement Total Quality Management (TQM). It mainly aims at exploring the approaches these organizations used to introduce TQM into the public sector, and to identify the factors that help or hinder successful implementation of TQM programs in the organizations under study.

The importance of the present research springs from its practical significance which provides us with first hand experience of implementing TQM programs in the Saudi public sector using snowballing method to identify organizations that implement TQM and metaplan method to interview managers and employees involved in implementing such TQM programs.

Research findings indicate differences among organizations under research in terms of main reasons for applications, level of implementation, units of application, type of TQM program adopted, training on TQM, employees understanding of TQM, leadership commitment, and statutes of TQM application.

In general, the efforts of adopting TQM philosophy in the Saudi public sector faces some difficulties which mostly relate to organizational and social factors, and it seems that there is a long way for TQM to prevail its benefits to Saudi managers and employees. The research ends with some outlined recommendations about the best ways of implementing TQM in the Saudi public sector.
\end{abstract}

\section{Introduction}

With limited resources on the horizon, and the likely prospect that we will have to meet our goals with less resources on every level, there is tacit acknowledgment that the time has come to shift to a new paradigm for reinventing government to find a new 
way of operation. Thus, the Saudi public organizations are witnessing a transfer of concern from just providing services to providing the same services with more style and more effectiveness and efficiency with the available resources. After most services have become available to people, the concern shifted to the quality and level of performance of these services, especially after the emergence of performance improvement techniques and several management models in a time of limited resources. Moreover, the distinguished governmental performance in the light of the previous concerns became a competitive quest and a necessity for governmental agencies survival.

Organizational change in the form of continuous improvement is the force that drives the Japanese government sector and the American public sector to utilize the managerial approaches and models of the Japanese corporations and factories such as theory "Z", Quality Circles, and Total Quality Management "TQM" which was defined by the U.S. Federal Quality Institute as "a strategic, integrated management system for achieving customer satisfaction. It involves all managers and employees and uses quantitative methods to improve consciously an organizations' process" (Harrison \& Stupak 1993, P. 417). This premise is an obvious indicator of determined and continuous attempts to improve the level of performance and quality of governmental services in such developed countries. Obviously, these administrative models and approaches have achieved a significant contribution and improvement in both quantity and quality. Because "TQM" is the most comprehensive and modern model, and because it is the most applicable to the public sector of the third world, this research will provide some inquiry of its applications in the Saudi public sector, and will review its success and problems in some of the Saudi public organizations.

This research was generally tended to evaluate the understanding of the concept of quality and detect its application and development in the Saudi public sector organizations. Also, it will explore the wider concept of TQM as understood by the public sector organizations. To explain the process of quality concern in the Saudi public sector organizations, the researchers will study services quality in these organizations and the effect of the TQM on some productivity programs in the public sector as well. After studying the different approaches of quality as perceived by the Saudi public sector organizations, the researchers will suggest some solutions to the problems that hinder the TQM applications, and will try to define and recommend some methods to deal with these problems that hinder this concept's application in the Saudi public sector.

\section{The Research Problem}

Introducing a long-term result-oriented approach for development in the public sector demands a tough struggle with so many challenges. TQM concept as the newest technique in organizational development has proven to be successful in private sector which encouraged the public sector's managers to try to adopt such concept as the most promising approach to cope with managing change and development challenges in the public sector, although they are faced with the matter of when and how to apply it as apposed to why should it be applied. Moreover, there are some critics who warn about TQM's transferability to all organizations, its high levels of initial investment, or the 
absence of operationalization. However, in the public sector, TQM is being considered as the necessary way toward modernizing the process that makes governments effective and fiscally responsive (Carr \& littman 1990, P. 17).

Quality is not totally a new term in the Saudi public sector organizations. However, developing a system for the implementation and achievement of quality and introducing such a system to different organizations does not seem to be an easy task. TQM came to endow an alternative method to provide quality and to achieve change and development for the Saudi public sector. However, TQM has been developed in different a culture and applied by diverse organizations in divergent settings, therefore, it will not be an easy task for the Saudi public sector's managers to adopt such concept, mainly because Saudi public sector has a different environment as opposed to the private or public sector in the developed countries that succeeded in introducing such approach. TQM is seen by the Saudi public sector managers as a long range process that requires discipline and significant organizational settings and investments. Furthermore, TQM as a continuous change method and a new approach that improves service, productivity, and reduces cost, needs to be learned and comprehended by the public sector managers and employees. Therefore, this research will concentrate on explaining the TQM for the Saudi public sector employees and discuss its applications in some of the Saudi Public Sector's organizations that have experienced such attempts. This paper, thus, will be directed to answer the following questions:

- What are the attempts of introducing TQM in the Saudi public sector ?

- How well do Saudi public sector managers and employees know about the TQM as a concept ?

- Was there any planning, timing or a caution when applying the "TQM" in the Saudi public sector organizations that applied such program ?

- Had those Saudi public organizations have to develop their own TQM Programs that can meet their cultural needs, organizational, and social structures, or they borrowed ready made programs?

- What administrative areas and productivity agents can "TQM" programs cover ? And have the utilized plan improve a Saudi public sector organization's quality of outcomes?

- By comparison, were there any differences in the process of TQM between the Saudi Ministries and public enterprises which applied such programs?

- Have these organizations established any special offices or departments to coordinate matters of quality, overlook and assist the adoption process of TQM, provide information, consultations and technical services for the adaptation?

- What were the difficulties that hindered the application of TQM in the Saudi public sector organizations? and how they can be overcome?

- Might there be any other barriers to prevent the other Saudi public sector organizations from adopting TQM ? 


\section{Importance of the Research}

Public sector organizations in the developing countries seek to introduce changes and improvement to their level of performance. It is clear that these organizations are continuously looking for new ways and methods of development, especially administrative methods which can assist in achieving effectiveness and efficiency. Therefor, this research subject receives its importance based on the argument that administration in an developing country such as Saudi Arabia, is always in state of development experience which must be reviewed and evaluated in order to push certain developmental efforts to alternate, or to terminate them. Since TQM is one of the newest and leading development techniques that has been adopted by some Saudi public sector organizations and others are moving toward implementing such program, this study provides insight for this new movement from the on going experience.

\section{Research Objectives}

This research aims to achieve the following goals:

1. Exploring the wider concept of TQM as being understood by the Saudi public sector organizations.

2. Studying the different approaches of quality as perceived by the Saudi public organizations, evaluating the quality concept, detect its application and development in the Saudi public sector organizations.

3. Identifying factors that are most likely to promote successful implementation.

4. Suggesting some solutions to the problems that hinder the TQM's application, defining, and recommending some methods to deal with these problems that hinder this concept's application in the Saudi public sector.

\section{Literature Review}

Most bureaucratic organizations in the third world countries have lost their willingness to change. The desired change, however, has come in a form of continuous improvement through the adaptation of TQM, which is perceived to be the most needed and the only path to survival for the next century. Since TQM promise to help organization to improve quality and to respond effectively to the public demands through continuous change, some Saudi public sector organizations with less certainty tried in different ways to adopt different TQM programs.

Trends that called for change through methods of continuous improvement -such as TQM and service quality- were ignited by the works and teachings of quality pioneers such as Crosby 1979, Feigenbaum 1983, Deming 1986; 1988, and Juran $1988 ; 1989$. The promises behind TQM is as clear as the compelling need for change in today's stressful political and economic environments.

Public sector organizations are faced with conflicting demands for productivity, quality, and service which increased the possibility of failure of any method of improvement. In such conflicting situations pubic sector organizations continuously search for a way that could help improving their performance through cost-cutting, training, and reorganization. Bureaucratic organizations are not able to respond to the 
public demands, and are still perceived as failing as well as searching for new ways of improvement. TQM emerged as a technique that seems to work for the private sector, especially in reducing waste and overall costs of operations. Thus, public sector organizations in many developed countries as well as third world countries start adopting TQM either because of the benefits this technique promises or in response to internal and external problems.

Continuous and long-term improvements, customer satisfaction, and full work force involvement are the main principles of TQM which are based upon the Japanese Kazine concept. It was first adopted at the private sector level, but soon it became a public sector quest and spread among its organizations as fast as in the private sector (Ishikawa 1985, PP. 132-159, Taguchi 1986, PP. 71-97). Effective implementation of TQM, as argued by its advocates, can improve organizational performance and effectiveness, boost productivity, reduce operating costs and errors, and ensure future survival (Crosby 1984, PP. 15-48, Deming 1986, PP.13-43, Reiker 1987, PP.3-11, Gabor 1988, PP.7-27, Barra 1988, P.7, Deming 1988, PP. 8-31, Dewar 1988, P.19, Scott 1989, P. 3, Rosander 1989, PP. 3- 39, Gitlow 1990, PP. 2-79, Juran 1991, PP.1052, Milakovich 1991, 14-28, Swiss 1992, P.78, P.101 , Kane 1992, PP. 60- 81, Galloway 1992, PP. 11-44, Bush 1992, 5-26, Berg 1993, PP. 17- 87, Carman 1993, PP. 30-91, Bester 1993, P.26, Garrity 1993, PP.26- 112, West, Berman, and Milakovich 1993, 201-239, Carr and Littman 1993, PP. 21-35). In contrast to the previous promises, however, only a minority of governmental organizations that have implemented TQM experienced waste reduction and cost cutting in overall quality expenses as well as red tapes, increased employee moral, reduced absenteeism and rework, improved effectiveness, increased productivity, increase sensitivity to customer, and major annual savings (Carlisle 1990, P.38, Moore 1990, P.321, Moore 1990, P.55, Brown and DeCrease 1991, PP. 9-21, Ritter 1991a, P.13-16, Ritter 1991b, P. 34, Burbidge 1994, PP. 5-7, Becker, Golomski and Lory 1994, PP.57-97). The majority of the organizations that have attempted to implement TQM failed to achieve the hoped 7 results because of many obstacles and less effective designed programs (Walker 1992, P. 63, Steele 1993, P.6-18, Merron 1994, P.39).

Some of the major problems that faced the application of TQM for starters were lack of strong leadership, strategic quality planning, effective human resources development and management, capability of managing quality process, and less concern about customer satisfaction and quality results (Kravchuke and Leighton 1993, PP. 70-72). Moreover, organizational culture, unempowered employees, and uncommitted top management were found to be some of the barriers that hinder the application of TQM in public organizations (Milakovich 1991, P.87). (AI-Qahtani 1993, P. 38) added that some of the other problems facing the application of TQM in public organizations were leadership frequent change, ambiguity of training and poor individual performance appraisal, different customers with different needs, weakness of financial and information systems, lack of ideal and effective type of organizations in the public sector, and the long period of time needed for the application of TQM.

In spite of this long range of previous studies and the contribution it provides to the application of TQM in the public sector, there is still a need for more research to pave the way for successful implementation of TQM and to point out the weaknesses in 
order to avoid failures, especially when the focus is on recent implementation attempts in the Saudi public sector organizations. Thus this study will first review the concept itself then examine these attempts in order to point out the strengths and weaknesses of such experiences and to provide methods to foster a successful adaptation of this new technique of management in the Saudi public sector organizations.

\section{Methodology and Procedures}

In this descriptive analytical study, the TQM concept was reviewed and then the Saudi public organizations that have developed a plan for the implementation of the TQM were identified through snowballing sampling, which is a method used when members of a universe cannot easily be located by random sampling (Simon and Burstein 1985, p. 123). In this method the researcher develops an ever- increasing set of sample observations, where you ask one participant in the event under study to recommend others for interviewing and so on (Babbie 1989, p. 289). He also used interviews to solicit data from a sample of managers to study these organizations efforts, and to explain their experiences. Then he used a metaplan method which is a powerful technique for running a constructive group interview (Management Improvements Ltd. 1994, p.14). This metaplan enabled him to ask the employees to identify and analyse factors that obstruct or foster the adaptation of TQM in Saudi public organizations and which might-from their point of view-impact other organizations that have not yet introduced any TQM programs.

Two main instruments were employed in this study. First, individual interviews were conducted with managers in supervisory levels who are occupying grades 8 and above in a pre-set appointment. Second, a metaplan was used for group discussions with employees involved in the application of TQM program at the same organization. the metaplan was designed in a way that it will not exert pressure on the participating members to disclose opinions or evaluations of specific experiences. This metaplan methodology helped to ensure that the participants express their opinions anonymously.

\section{Population and Sampling}

The population of this study has to be all public sector organizations that have started any sort of program for TQM application regardless of their type (ministries, public enterprises, agencies, presidencies, and others). These organizations are sorted out by using snowballing method through which we tried to identify public organizations that have attempted to apply TQM programs or were in the process of doing so. By administering snowballing sampling we found that six organizations have applied TQM programs. One of these organizations (Saudi Consolidated Electric Company-East, SCECO-East) did not cooperate by neither providing any information about their program nor allowing their employees to spend time with the researchers, therefore, it was excluded from the study. By excluding SCECO-East we found the public organizations that have applied TQM programs were only five organizations which represent our sampling fields from which we sampled our targeted population of managers and employees. 
We started, first, interviewing people and conducting metaplan with the Ministry of Post, Telegraphs and Telephones (PTT). Then, we asked PTT employees, concerned with TQM, to suggest other governmental organizations that have attempted or are attempting to apply TQM, and so on until we surveyed all the public sector. To move from one organization to another, we pursued the most frequent mentioned organizations. To select our sample of employees we were concerned only with those involved with applying TQM, where we interviewed managers and use metaplan with the sampled employees in groups of at least ten employees. Each group were met based on a pre-scheduled meeting where the plan was explained to them first, and then we started the process of the metaplan by discussing their understanding and experience of the TQM and other concerns of this research.

Using the previously mentioned methodological techniques, only two ministries and three public enterprises experienced TQM application process. The Ministries are the Post, Telegraphs, and Telephones (PTT) Ministry, and Ministry of Health (MOH); while the enterprises are the Institute of Banking (IOB), Saudi Airlines (Saudia) and Saudi Arabian Petrochemicals Company (SAPC). However, the process of TQM application in each of these organizations vary from one to another where some of these organizations are still in the beginning or already in the zenith of its efforts, others either slowing down or stopping their efforts in implementing TQM completely.

The results of this research are presented and discussed in following sections.

\section{Research Findings and Discussion}

The outcomes of this research will be presented in several categories according to the following classification: A. Evaluating organizations' efforts according to TQM factors, B. Evaluating TQM activities in each program, and C. Identifying problems facing TQM application.

\section{A. Evaluation Based on TQM Factors}

As a result of the research investigation, it was found that there are some differences between the organizations with regard to their statutes according to the TQM factors. TQM factors that were used as evaluation tools were as follows: (1) Goal of implementation, this factor was measured by the main reason for the application; (2) level of implementation which was measured by the extent of implementation of TQM to the organization's departments; (3) unit of application which was measured by the subject of the program; (4) TQM original program which was measured by the originality of the. program; (5) training on TQM which was measured according to location of training; (6) employees understanding of TQM which was measured by asking the employees to state their definition of TQM and then compare that to the definition stated earlier in this research; (7) commitment of leadership which was measured by the size of support and level of commitment the leadership is giving to the program; (8) status of TQM application which was measured by the program activity; (9) years of experience with TQM, which was measured by the length of the period the organization experience with the program. Thus, agencies were evaluated independently according to these factors (see Table 1). 
Table (1)

Evaluation of Public Organizations Statutes on TQM Factors

\begin{tabular}{|c|c|c|c|c|c|}
\hline TQM Factor & PTT & $\mathrm{MOH}$ & SAPC & SAUDIA & IOB \\
\hline $\begin{array}{l}\text { Main reasons for } \\
\text { application }\end{array}$ & $\begin{array}{c}\text { Need for } \\
\text { development }\end{array}$ & $\begin{array}{l}\text { Quality } \\
\text { Assurance }\end{array}$ & $\begin{array}{l}\text { Developing } \\
\text { Competition }\end{array}$ & $\begin{array}{l}\text { Improve } \\
\text { customer } \\
\text { services } \\
\end{array}$ & $\begin{array}{l}\text { Develop } \\
\text { management } \\
\text { performance } \\
\end{array}$ \\
\hline Level of factor & Partial & Partial & Partial & Partial & Comprehensive \\
\hline $\begin{array}{l}\text { Unit(s) of } \\
\text { application }\end{array}$ & $\begin{array}{c}\text { Operation } \\
\text { and } \\
\text { Maintenance }\end{array}$ & Hospitals & $\begin{array}{l}\text { Main } \\
\text { Office }\end{array}$ & $\begin{array}{l}\text { Customer } \\
\text { Service } \\
\text { division }\end{array}$ & Management \\
\hline $\begin{array}{l}\text { Type of TQM } \\
\text { program adopted }\end{array}$ & $\begin{array}{l}\text { Australian } \\
\text { Program }\end{array}$ & $\begin{array}{c}\text { Own } \\
\text { program }\end{array}$ & $\begin{array}{c}\text { Own } \\
\text { program }\end{array}$ & $\begin{array}{c}\text { Own } \\
\text { program }\end{array}$ & $\begin{array}{c}\text { TQM } \\
\text { academy }\end{array}$ \\
\hline $\begin{array}{l}\text { Training on } \\
\text { TQM }\end{array}$ & $\begin{array}{l}\text { In house } \\
\& \text { abroad }\end{array}$ & In house & $\begin{array}{l}\text { In house } \\
\& \text { abroad }\end{array}$ & In house & In house \\
\hline $\begin{array}{l}\text { Employees } \\
\text { understanding of } \\
\text { TQM }\end{array}$ & $\begin{array}{c}\text { Partially } \\
\text { understood }\end{array}$ & $\begin{array}{c}\text { Partially } \\
\text { understood }\end{array}$ & $\begin{array}{c}\text { Fully } \\
\text { understood }\end{array}$ & $\begin{array}{c}\text { Fully } \\
\text { understood }\end{array}$ & $\begin{array}{c}\text { Partially } \\
\text { understood }\end{array}$ \\
\hline $\begin{array}{l}\text { Leadership } \\
\text { Commitment }\end{array}$ & $\begin{array}{l}\text { Leadership } \\
\text { was } \\
\text { committed } \\
\end{array}$ & $\begin{array}{l}\text { Leadership is } \\
\text { committed }\end{array}$ & $\begin{array}{l}\text { Leadership is } \\
\text { committed }\end{array}$ & $\begin{array}{l}\text { Leadership } \\
\text { is } \\
\text { committed }\end{array}$ & $\begin{array}{c}\text { Leadership was } \\
\text { not committed }\end{array}$ \\
\hline $\begin{array}{l}\text { Statutes of TQM } \\
\text { application }\end{array}$ & $\begin{array}{c}\text { Slowing } \\
\text { down }\end{array}$ & $\begin{array}{c}\text { Slowing } \\
\text { down }\end{array}$ & $\begin{array}{l}\text { In its } \\
\text { zenith }\end{array}$ & $\begin{array}{l}\text { In its } \\
\text { zenith }\end{array}$ & Stopped \\
\hline $\begin{array}{l}\text { Years of } \\
\text { Experience with } \\
\text { TQM program }\end{array}$ & Since 1992 & Since 1990 & Since 1993 & Since 1991 & $\begin{array}{c}\text { Between } 1990 \\
\text { and } 1996\end{array}$ \\
\hline
\end{tabular}

Post, Telegraphs, and Telephones Ministry (PTT): The PTT started its program since 1992, and the employees seem to understand the TQM partially because of the discontinuity of application and the change of leadership. TQM program is partially implemented in some departments of the ministry and it is slowing down too. The PTT adopted the nine steps of Telecom Australia's program with some modifications, and trained its employees for TQM both in house and abroad. The unit of application started with the operation and maintenance division with an intention of generalizing TQM application to all Ministry divisions if it succeeded in the operation and maintenance division.

The Ministry of Health (MOH) is encouraged to apply TQM because of its desire to achieve high quality assurance in its health services. Although it started its program since 1990, the level of TQM implementation in the Ministry of Health is partial because it concentrates on hospitals as units of application. The Health Ministry is developing its own program and measurement, but depending on some theoretical literature as a guide for TQM application. The training for TQM is carried out in house where the Ministry is conducting different training seminars in different hospitals carried out by local and/or international trainers. Only those people involved in the process of TQM application understand what is TQM all about. The top management is involved in the process and is encouraging TQM application through the control department which is responsible for quality as one of its responsibilities. At the time of this research, the responsibility of applying TQM is being transferred to the 
hospitals themselves instead of being centralized at the Ministry level, and the process is slowing down slightly.

Saudi Arabian Petrochemicals Company $(S A P C)$ is working on a competitive market which was the driving force behind the adaptation of TQM program in 1993. SAPC started with some managerial functions in the management section in Riyadh as a pilot test for TQM application. This partial application of the TQM program in the headquarter office was developed by SAPC development division. Employees were trained on TQM application abroad as well as at home. They seem to understand fully TQM which facilitate the process of 13 application, especially with the strong commitment of the top management. However, this TQM program is still at its zenith although it is expected to slow down as management started to think of broadening the application.

Saudi Airlines (Saudia) as an enterprise that works in a competitive market is concerned with its customers services. Thus, it adopted TQM program as a method to improve customer service in Saudia since 1991. The start was partial because it was limited only to customer services and human resources programs in Riyadh and Jeddah. TQM programs in Saudia were developed at their development department with the assistance of some local consultants, and the training was performed mainly at home except for very few participants who were trained abroad. TQM techniques were fully understood by all participants who have been trained. This was a result of top management encouragement. In fact, Saudia top management seems to be committed strongly to it. Similar to TQM application in SABAC, TQM programs in Saudia are in their zenith as well.

The Institute of Banking $(I O B)$ is an evolving organization with an intention of being a top training institute for about eleven banks working in Saudi Arabia. The IOB adopted TQM between 1993 to 1996 to develop its management performance in all levels across the institute. The TQM program that was adopted was developed by The Proudfoot Crosby in Florida. Training on this program was carried out at home with the assistance of some American consultants. Employees understanding of the TQM concept, however, was partial. Although, leadership was very supportive of the TQM program at the beginning, it soon called for the end of such experience because of its high cost, leading to the termination of the TQM program early 1996. It was finally replaced with internally-designed approach to development

\section{B. Evaluation Based on TQM Activities}

Another method for evaluation of the TQM application in the Saudi organizations mentioned above, is the TQM activities carried out by the different organizations. It was found that there are some 14 differences between these organizations in the activities of leadership, employee training and recognition, strategic planning, customer focus, empowerment and teamwork, measurement and analysis, results and quality assurance. In this section, a comprehensive evaluation will be used where we will discuss all organizations according to each activity in order to be able to give some comparative evaluation. 
Leadership: It is clear that leaderships of all organizations were committed to TQM application as appeared through documents and communications. Leadership in these organizations have had some sort of TQM awareness training, ranging from short seminars for leaders of PTT and MOH to medium training courses for leaders of SAPC, Saudia and IOB. The IOB was the only organization to create quality council while the rest depended on steering committees. The PTT, MOH and IOB seem to abandon any new policies for further improvements and are moving toward some new concepts along with the standing TQM programs. SAPC and Saudia are still developing new policies for TQM improvements.

Employees Training and Recognition: Employees training and recognition was found in the PTT and MOH. This was probably a result of the fact that these two organizations are fairly large. Training and recognition in SAPC, Saudia and IOB was comprehensive, detailed and clear. Training was conducted at home and abroad as well. Employees in these three organizations seem to be recognized clearly when compared to the others in the PTT and MOH.

Strategic Planning: None of the five organizations we studied has a clearly developed quality vision, mission or policy statement. However, SAPC, IOB and Saudia are developing TQM implementation plans. The PTT and $\mathrm{MOH}$ in their experience relate teams goals to implementation goals, while the IOB and Saudia use strategic planning process to link their organizations overall strategic plan to quality strategic plan.

Customer Focus: While the IOB and SAPC are the only two organizations to wary about their internal customers and their needs' while the PTT, MOH and Saudia are focusing on their external customers and their requirements and satisfaction. Different mechanisms are used by the organizations to anticipate internal and external customers' needs.

Empowerment and Teamwork: The IOB, SAPC and Saudia seem to worry more about employees satisfaction. Thus, they frequently conduct an assessment of employees satisfaction. In the meantime, Saudia and PTT encourage services innovations. They share, with all organizations under study, the tendency to establish TQM teams, involve employees in quality initiatives and create a formalized improvement process.

Measurement and Analysis: All organizations under study frequently asses their readiness and culture for TQM implementation. This seems to be an excuse for slowing down the process, such as in the PTT, MOH and IOB. Only SAPC and Saudia demonstrated a continuous improvement in the process. In addition, the PTT and $\mathrm{MOH}$ are the only organizations that analyze the systems and processes to streamline operation to improve productivities. While Saudia, IOB and MOH have concentrated on developing internal measures of quality and productivity, PTT and MOH developed external measures of quality and productivity.

Quality Assurance: SAPC, MOH and Saudia are the only organizations concerned with quality assurance. These organizations, especially $\mathrm{MOH}$, have given a great 
attention to quality assurance activities, work with suppliers to improve quality, and use quality assurance methods to make sure that quality is being achieved.

Results: Although many results have not been achieved in the organizations under study, all organizations seem to look for the improvement of processes and substantial cost savings, meet quality improvement goals, set new ones, and finally improve in work quality and process throughout the organization. However, using processes for bench marking and applying for a quality award seems to be far away for all organizations in this study.

\section{Problems facing TQM application}

This research found that there are some problems pertaining to the application of TQM programs in some Saudi public sector agencies. The most apparent problem is the limited implementation.

TOM programs throughout all the organizations involved in this research, except of the IOB which had all of its departments involved in the implementation, but finally quit the program. The other main problem results from the change in leadership in all organizations which reflects on their commitment to TQM programs implementation. However, IOB top manager has not been changed but shifted his support to the TQM program to other concerns. The process of TQM implementation is slowing in PTT and $\mathrm{MOH}$, and completely stopped in IOB which provide a sign of hesitance to implement TQM by the Saudi public organizations. These problems appear to be related to weak understanding of the TQM and its implementation goal in most of the organizations we analyzed. Moreover, the training on TQM does not seem to be efficient, it is conducted mostly in house where there is no experience to offer, not to mention the fact that the complexity of TQM training programs and the lack of posttraining consultations were factors that hindered the efforts of these organizations in their implementations of TQM.

As a result of the metaplan analysis, it was found that there are some lack of quality vision development in all of the organizations we studied. Moreover, there was no clear mission statement or even policy statements for the employees to use as a guide during execution of their tasks. While discussing implementation with employees of these organizations, they do not seem to have any bench marking to shoot for nor they were aware of bench marking. Furthermore, there was no significant indications of any improvement of work process in the department implementing TQM which does not allow for any application for TQM awards at any level. In summary, it appears from the metaplan analysis that results had not been promising nor achieved at any level in all of the organizations under evaluation.

\section{Conclusion and Recommendations}

The previous attempts of introducing TQM in the Saudi public sector were found only in the Ministry of Post, Telegraphs, and Telephones (PTT), and Ministry of Health $(\mathrm{MOH})$, as well as some attempts of TQM applications by the Institute of Banking (IOB), Saudi Airlines (Saudia) and Saudi Arabian Petrochemicals Company (SAPC). However, it appears that TQM application in the Saudi public sector dose not show a great success, mainly because of the change of leadership and high cost of the 
programs. It is clear that these organizations have different experiences with different approaches. Thus, the conclusion we can draw here is that these organizations have tried to adopt TQM, each one in its own way, without any kind of education or coordination from an experienced organization locally. They could not, as a result, achieve any progress toward achieving TQM goals. According to the metaplan used in this study most employees were driven without being convinced to participate in the TQM implementation which was reflected on their poor performance and the organization overall outcomes.

Herein, we suggest ways to overcome the problems that hinder the TQM implementation in the organizations involved in this research, and introduce some recommendations for the 'other Saudi public sector agencies that tend to implement TQM. These organizations need a stable and committed leadership that can support and understand the necessity to implement TQM, and develop quality vision, mission statement, and policy for all members of the organization. Also, such organizations ought to rethink their plans to implement TQM and reassess their efforts to educate and train all of their employees on the TQM requirements of implementation. In short, these organizations need to reconsider the role of its leaders, evaluate their education and training programs, and enlighten all of their employees about TQM.

Some recommendations, related to the findings of the research, and are directed to the five Saudi public sector organizations that are implementing TQM, are listed below:

1. Organizational leadership should be stable at least for quite some time in order to help maintaining successful implementation of TQM programs.

2. Some of the organizations under study stop or slow their efforts on implementing TQM programs, while they should have given these programs enough time to produce fruitful results, because it is known that TQM programs need at least eight years to produce full impact on the organization.

3. These organizations should extend TQM application to all departments in order to achieve the possible advantages of TQM.

4. More training and encouragement for change should be provided to the employees of these organization so they create full understanding of TQM.

Some other general recommendations that can be directed to any public organization that implement or tend to implement TQM are as follows:

1. Before starting the process of TQM implementation, public sector organizations in general should analyse their environment and assess the applicability of TQM through seeking technical advice and consultations from the agencies specialized in administrative developmental fields locally or worldwide.

2. Such organizations leaders and employees have to be well informed about the benefits of TQM, and committed to TQM implementation. This can be achieved through effective education and intensive training programs in house, local or internationally. 
3. Organizational development agencies such as the Institute of Public Administration (IPA) and the Central Department for Administration and Organization in the Ministry of Finance and National Economy should increase its understanding and experience to become authoritative consultant agencies to be able to organize training sessions on TQM implementation for employees of interested public organizations as a gesture of encouragement to public sector organizations to implement TQM.

4. Research has to be oriented and directed extensively to TQM in order to evaluate and recognize any possible difficulties that might hinder the implementation process, and suggest solutions to meet such barriers.

5. Conferences and organizational public debates can be supported by the public sector agencies before introducing such change. It is hoped that this will increase the acceptance of TQM by the employees and the other stakeholders.

6. In order to lead TQM implementation and to avoid similar problems as we found above, any public sector organization should have a well trained and educated team before starting to implement TQM program. Such team can be organized as a department within the organization that takes responsibility of TQM implementation and development.

7. Public organizations intending to implement TQM should review the experience of the organizations that had started or tried, but did not continue the implementation. It is highly expected that they will learn from their experiences and they may avoid any deviation by such leading organizations.

\section{References}

AI-Qahtani, Salem S. (1993), "Possibility of TQM Application in the Saudi Public Sector", Public Administration (78), pp. 5-26.

Babbie, E. (1989), The Practice of Social Research. Belmont, CA: Wadsworth Publishing Company.

Barra, R. (1988), "Mobilizing for Quality", The Journal for Quality and Participation (11), pp. 28-33.

Becker, S., Golomski, W., and Lory, D. (1994), "TQM and Organization of the Firm: Theoretical and Empirical Perspectives", Quality Management Journal (1), pp. 18-24.

Berg, D. (1993), "Experience Can be the Worst Teacher", The Journal for Quality and Participation (16), pp. 24-26.

Bester, Y. (1993), "Net-Value Productivity: Rethinking the Cost-of-Quality Approach", Quality Management Journal (1), pp. 71-76.

Brown, J. and DeCrease, W. (1991), "The First Baldridge-Based Community Quality Award", The Journal For Quality and Participation (14), pp. 82-88.

Burbidge, J. (1994), "A Participative Model of Community Development", The Journal of Quality and Participation (17), pp. 14-18.

Bush, G. (1992), "The Importance of Quality", The Journal Of Quality and Participation (15), pp. 6-8.

Carlisle, J. (1990), Customer Service Team as an Intervention Strategy in Public Sector. Paper Presented at the AOP Spring Conference Transactions.

Carman, J. (1993), "Continuous Quality Improvement as a Survival Strategy: The Southern Pacific Experience", California Management Review (35), pp. 118-132. 
Carr, D. and littman, I. (1993). Excellence in Government: Total Quality Management in the 1990s. 2nd ed. Arlington, VA: Coopers and Lybrand.

Carr, D. and littman, I. (1990), Excellence in Government: Total Quality Management in the 1990s. New York: Coopers and Lybrand.

Crosby, P. (1979), Quality Is Free. New York: McGraw-Hill Book Company.

Crosby, P. (1984), Quality Without Tears. New York: McGraw-Hill Book Company

Deming, W. (1986), Out of The Crises. Cambridge, MA: Massachusetts Institute of Technology Press.

Deming W. (1988), "The Need for Change", The Journal for Quality and Participation (11), pp. $48-49$.

Dewar, D. (1988), "Beware", The Journal for Quality and Participation (11), pp. 34-37.

Feigenbaum, A. (1983), Total Quality Control. New York: McGraw-Hill.

Gabor, C. (1988), Yes, It Can Be Done; Ten Steps to Measuring and Improving Quality and Productivity in the Public and Service Sectors. Paper Presented at the AOP Spring Conference Transactions.

Galloway, R. (1992), "Quality Improvement and Heightened Self-Esteem: The Brighton Police Story", National Productivity Review (11), pp. 453-461.

Garrity, R. (1993), "Total Quality Management: An Opportunity for High Performance in Federal Organizations", Public Administration Quarterly (16), pp. 430-459.

Gitlow, H. (1990), Planning For Quality, Productivity, and Competitive Positions. Homewood, IL: Dow Jones-Irwin.

Harrison, S. and Stupak R., (1993), "Total Quality Management: The Organizational Equivalent of Truth in Public Administration, Theory and Practice", Public Administration Quarterly, vol. 16, No. 4, pp.416-428.

Ishikawa, K. (1985), "Group Wide Quality Control", The Journal Of Quality and Participation (11), pp. 4-6.

Juran, J. (1988), "Managing For Quality", The Journal for Quality and Participation (11) pp. $8-12$.

Juran, J. (1989), Juran on leadership for Quality. New York: The Free Press.

Juran, J. (1991), "Strategy for World-Class Quality", Quality Progress (24), pp. 81-85.

Kane, E. (1992), "Implementing TQM at Dunn and Bradstreet Software", National Productivity Review (11), pp. 4405-416.

Kravchuke, R. and Leighton, R. (1993), "Implementing Total Quality Management in The United States", Public Productivity and Management Review (17), pp. 70-82.

Management Improvements Ltd. (994), Metaplan Applications. New York, NY:1.

Merron, K. (1994), "Creating TQM Organizations", Quality Progress (27), pp. 51-54.

Milakovich, M. (1991), "Total Quality Management In The Public Sector", National Productivity Review (10), pp. 195-213.

Ministry of Health Annual Reports, (1990), Saudi Arabia, Riyadh (1991-1995).

Moore, E., "Transforming People and a City", The Journal for Quality and Participation (13), pp. 74-76.

Post, Telegraphs, and Telephones Ministry Annual Reports (1995), (1991-1995), Saudi Arabia, Riyadh.

Reiker, W. (1987), "Where Are We Headed?", The Journal for Quality and Participation (10), pp. 32-36.

Ritter, D. Let's Elevate Quality on Our National Agenda", National Productivity Review (10), Autumn 1991a: 447-452.

Ritter, D. "America's Quality Revolution", The Journal for Quality and Participation (14), March 1991b: 60-63.

Rosander, A. (1989), The Quest For Quality in Services. Milwaukee, WI: ASOC Quality Press. 
Saudi Airlines Annual Reports (1996), (1990-1996), Saudi Arabia, Jeddah.

Saudi Arabian Monetary Agency (1994), (1990-1994) Institute of Banking Annual Reports, Saudi Arabia, Riyadh.

Scott, W. (1989), "TQM Expected to Boost Productivity, Ensure Survival of U.S. Industry", Aviation Week and Space Technology, December 1989, pp. 64-69.

Simon, J. and Burstein, P. (1985), Basic Research Method in Social Science. New York, NY: Random House.

Steele, J. (1993), Implementing Total Quality Management for Long-and Short-Term Bottom Line Results", National Productivity Review (12), pp. 425-441.

Swiss, J. (1992), "Adapting Total Quality Management (TQM) to Government", Public Administration Review (52), pp. 356-362.

Taguchi, G. (1986), Introduction to Quality Engineering. Dearborn, Michigan: American Supplier Institute Inc.

Walker, T. (1992), "Creating Total Quality Improvement That Lasts", National Productivity Review (11), pp. 473-478.

West, J., Berman, E., and Milakovich, M. (1993), "Implementing TQM in Local Government: The Leadership Challenge", Public Productivity and Management Review (17), pp. 175189. 
تطبيق إدارة الجودة الشاملة في بعض الأجهزة الحكومية السعودية

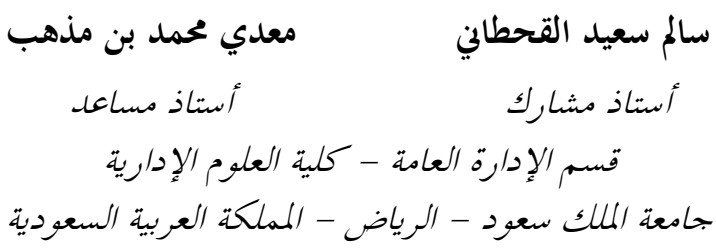

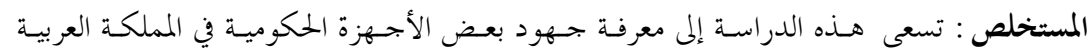

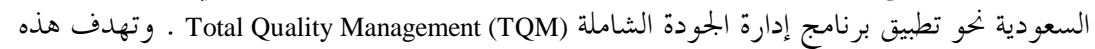

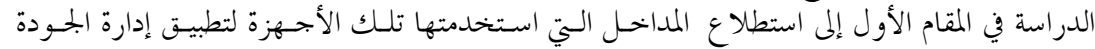

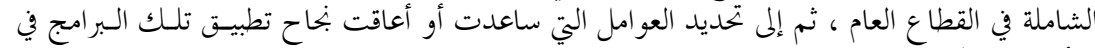

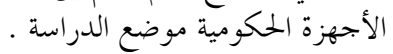

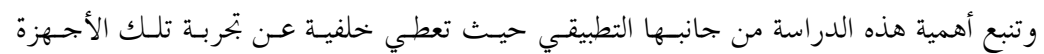

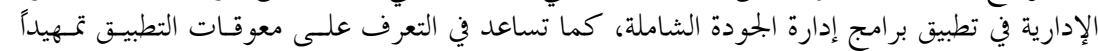

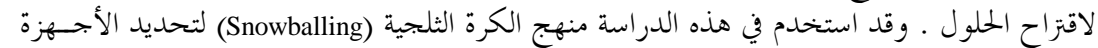

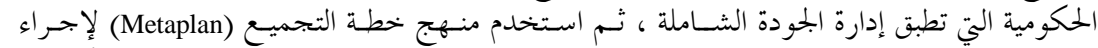

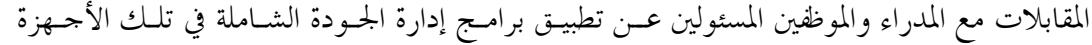
الحكومية . المقابلات مع

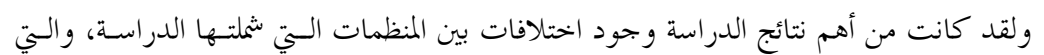

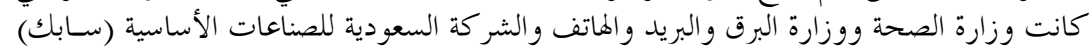

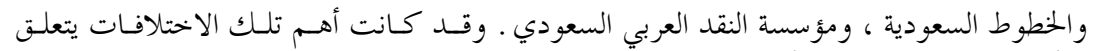

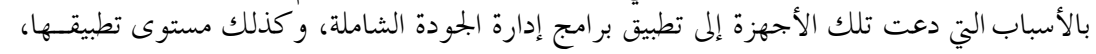

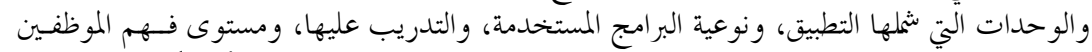

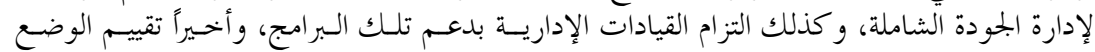

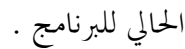

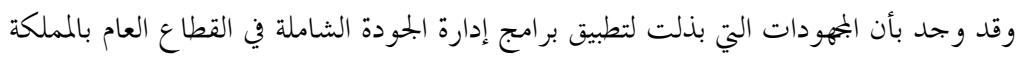

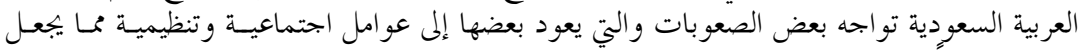

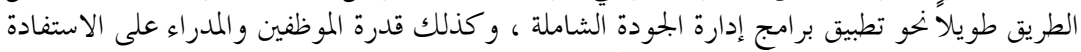

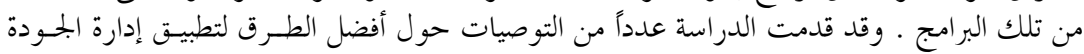

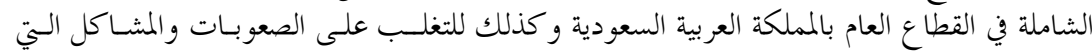

